\title{
SISTEM PENJADWALAN MATA PELAJARAN MENGGUNAKAN ALGORITMA GENETIKA
}

\author{
Yesri Elva \\ Program Studi Sistem Informasi, Fakultas Ilmu Komputer, Universitas Putra Indonesia “YPTK”, Padang \\ Sumatera Barat, Indonesia. \\ y3sri3lvalgmail.com
}

\begin{abstract}
Schedule is one important factor to support the learning process, one of which at SMKN 3 Pariaman. In SMKN 3 Pariaman scheduling process is still done manually, consequently there are conflicting schedules and timing of learning becomes too late. One of completion method to the problem is to use a genetic algorithm, because it is one of the Genetic Algorithm optimization algorithm that is robust and can be used on a wide variety of case studies such as scheduling. This algorithm is also often used to find the optimal solution both in the case of simple to complex problemsolving technique that determines the start and initialization pupulasi chromosomes, determine the value of fitness, selection, crossover, mutation. Mutations done to produce the best fitness value which can be used to determine the final outcome scheduling. If the best fitness values have been obtained, the process is stopped and reach the finish condition. Keywords - Genetic Algorithms, Scheduling
\end{abstract}

Abstrak - Jadwal merupakan salah satu faktor penting untuk penunjang proses belajar mengajar, salah satunya pada SMKN 3 Pariaman. Pada SMKN 3 Pariaman proses penyusunan jadwal masih dilakukan secara manual, akibatnya masih terdapat jadwal yang bentrok dan waktu pelaksanaan belajar mengajar menjadi terlambat. Salah satu metode untuk penyelesain masalah tersebut adalah dengan menggunakan algoritma genetika, karena Algoritma Genetika merupakan salah satu algoritma optimasi yang kuat dan bisa digunakan pada berbagai macam studi kasus seperti penjadwalan. Algoritma ini juga sering digunakan untuk mencari solusi optimal baik pada kasus yang sederhana sampai yang rumit teknik pemecahan masalahnya yaitu menentukan pupulasi awal dan inisialisasi kromosom, menentukan nilai fitness, seleksi crossover, mutasi. Mutasi dilakukan sampai menghasilkan nilai fitness terbaik yang dapat digunakan untuk penentuan hasil akhir penyusunan jadwal. Jika nilai fitness terbaik sudah didapatkan maka proses dihentikan dan mencapai kondisi selesai. Kata kunci - Algoritma Genetika, Penjadwalan

\section{PENDAHULUAN}

Algoritma Genetika merupakan salah satu algoritma optimasi yang kuat dan bisa digunakan pada berbagai macam studi kasus karena menggunakan prinsip teori evolusi. Algoritma ini sering digunakan untuk mencari solusi optimal baik pada kasus yang sederhana samapai yang rumit. Algortima genetika bekerja pada suatu populasi yang dibentuk oleh kasus yang direpresentasikan sebagai kromosom dan akan dievaluasi untuk memperoleh seberapa nilai optimalnya.

Algoritma genetika ini telah banyak diaplikasikan untuk penyelesaian masalah dan permodelan dalam bidang teknologi, bisnis, dan entertainment, seperti optimasi penjadwalan, pemograman otomatis, machine learning, model ekonomi, model sistem imunisasi, model ekolagis, interaksi antara evolusi dan belajar. Pada penelitian sebelumnya yang dilakukan di Universitas udayana, dilakukan optimasi penjadwalan dengan algoritma genetika, dimana penelitian tersebut menghasilkan dan memperlihatkan bahwa algoritma genetika dapat digunakan dalam pembuatan jadwal optimal dengan tidak adanya bentrok antar jadwal kuliah, waktu dan ruangan. Penelitian ini akan mencari bentuk dari penjadwalan dengan menganalisis dan membandingkan metode pengembangan crossover dan mutasi dalam algoritma genetika dengan metode konvensional yang ada. dari hasil penelitian ini akan mencari metode crossover mana yang lebih baik digunakan untuk mendapatkan jadwal yang sesuai tersebut. Metode yang lebih baik akan terlihat dari nilai fitness yang dihasilkan. (Made Darma Yunantara, dkk (2011).

Algortima genetika ini digunakan oleh Tamilarasi and Kumar (2010), untuk pemecahan masalah penjadwalan job-shop menggunakan Algoritma Genetika hybrid (GA) dengan Simulated Annealing (SA). Algoritma genetika ini juga digunakan oleh Sbeity.dkk (2014). Hasil penelitiannya mengenai penggabungan Analytical Hierarchy proses dan algoritma genetika untuk memecahkan masalah penjadwalan. AHP digunakan untuk menghitung skor setiap guru yang timbul dari satu set informasi yang diberikan.

Berdasarkan hal yang penulis uraikan diatas maka penulis merancang sebuah sistem yang dapat mengatasi masalah-masalah diatas, penulis mencoba merancang sebuah Sistem Informasi penjadwalan dengan algoritma genetika. Penulisan ini penulis beri judul, " Perancangan Sistem Penjadwalan Mata Pelajaran menggunakan Algoritma Genetika “

\section{METODE PENELITIAN}

Penelitian ini dilakukan di SMKN 3 Pariaman, dimana penelitian ini dilakukan dalam 
beberapa tahap seperti yang terlihat pada gambar dibawaah ini :

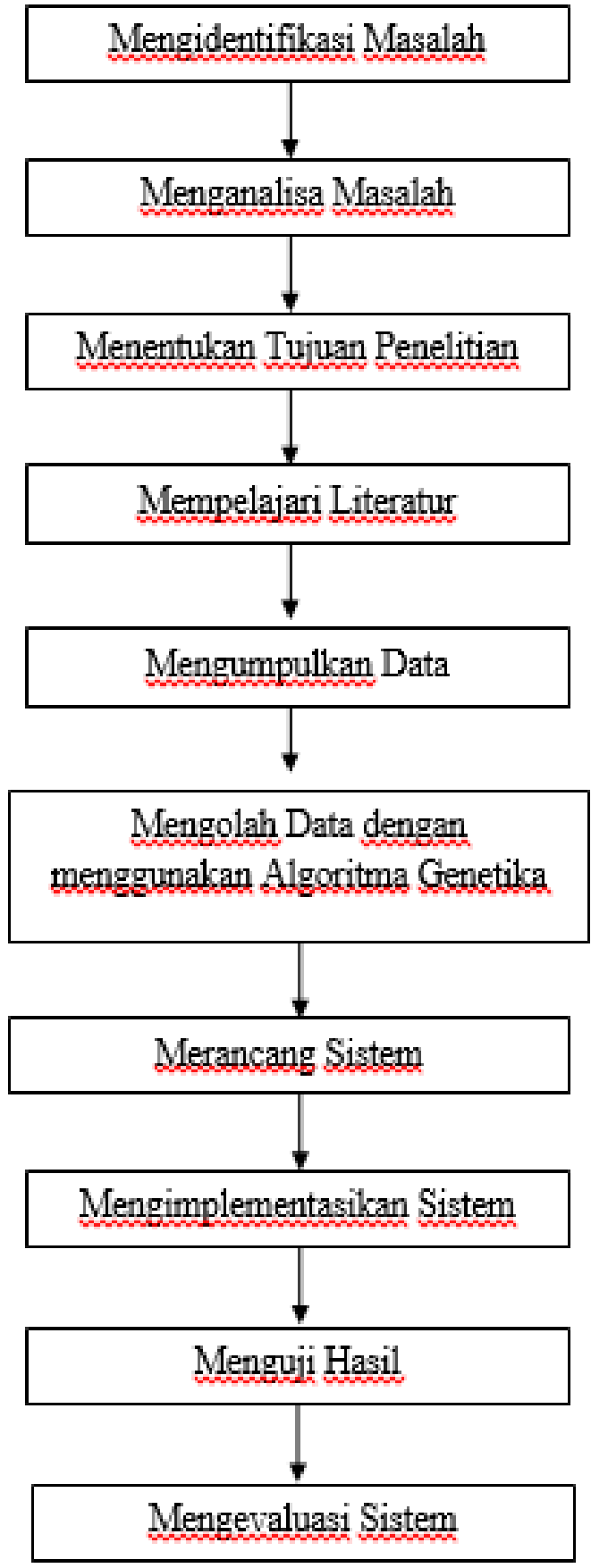

Gambar 1: Kerangka Penelitian

1. Mengidentifikasi Masalah

Tahapan ini bertujuan untuk menjaga konsistensi dari penelitian sehingga peneletian yang dilakukan lebih terarah dan tujuan yang diharapkan dapat tercapai. Tahapan identifikasi masalah dimulai dengan memeperhatikan susunan jadwal mata pelajaran yang awalnya dibuat secara manual.
2. Menganalisa Masalah

Dalam melakukan analisa masalah peneliti melakukan beberapa cara dan metode diantaranya metode deskriptif. Pada metode ini data yang akan dikumpulkan, disusun, dikelompokkan, dianalisa sehingga diperoleh beberapa gambaran yang jelas pada masalah penelitian. Maka diharapkan masalah dapat dipahami dengan baik dan benar, sehingga dapat ditarik kesimpulan dan mendapatkan solusi untuk menyelesaikan masalah.

\section{Menentukan Tujuan Penelitian}

Berdasarkan perumusan masalah yang telah dibuat pada tahap sebelumnya, maka tahap penentuan tujuan berguna untuk memperjelas kerangka tentang apa saja yang menjadi sasaran dari penelitian ini. Pada tahap ini ditentukan tujuan dari penelitian ini adalah bagaimana merancang dan mengimplementasikan metode algoritma genetika yang memudahkan dalam proses penyusunan jadwal mata pelajaran.

\section{Mempelajari Literatur}

Melalui studi literatur, dipelajari teori-teori yang berhubungan dengan algoritma genetika, khususnya tentang penggunaan algoritma genetika untuk penyusunan jadwal mata pelajaran. Sumbernya berupa buku, jurnal, maupun situs internet yang berhubungan dengan algoritma genetika.

\section{Mengumpulkan Data}

Data penelitian ini dikumpulkan dari observasi,buku - buku dan situs yang berhubungan dengan algoritma genetika serta data dari sekolah yaitu data mata pelajaran beserta data guru dan kelas.

6. Mengolah Data dengan Algoritma Genetika

Dari hasil pengumpulan data selanjutnya dilakukan analisis untuk membuat disain atau rancangan program. Setelah itu digunakan algoritma genetika untuk melakukan pengolahan data untuk penyusunan jadwal mata pelajaran.

\section{Merancang Sistem}

Pada tahap ini program akan didisain dan dirancang terlebih dahulu dengan menggunakan bahasa pemograman PHP . Hasil dari tahap ini adalah untuk mendapatkan model perangkat lunak. Model perangkat lunak yang sudah jadi akan diuji coba sebelum akhirnya diimplementasikan.

8. Mengimplementasikan Sistem

Sistem penjadwalan yang dikembangkan diimplementasikan. Karena itu, untuk pembangunan sistem penjadwalan ini dibutuhkan 3 (tiga) komponen yang harus dipenuhi. Komponen tersebut adalah:

\section{Hardware (perangkat keras)}

Hardware adalah sejumlah perangkat yang terlihat secara fisik yang diperlukan untuk penyimpanan dan pengolahan data pada sistem 
penjadwalan ini ini. Adapun hardware yang digunakan untuk membangun sistem penjadwalan ini adalah :

a. Laptop Axio Intel Core2 Duo.

b. Hardisk 896 MB RAM 1 Gigabyte.

c. Printer Cannon iP2770 PIXMA.

2. Software

Software merupakan program komputer yang terdiri dari instruksi-instruksi pada saat mengoperasikan perangkat komputer. Dalam pembangunan sistem penjdwalan ini, penulis menggunakan beberapa software di antaranya sebagai berikut:

a. XAMPP For Windows 2.5

b. Google chrome dan Modzilla FireFox sebagai web browser.

c. Notepad ++ .

d. Sistem operasi Microsoft Windows XP.

e. Tools untuk pemrograman yaitu PHP MySQL

f. Database yang digunakan adalah MySQL.

3. Brainware

Brainware adalah pihak atau orang yang terlibat dalam pembangunan sistem penjadwalan ini yaitu :

a. Administrator

Administrator adalah orang yang mengelola sistem penjadwalan ini, dan administrator juga yang memasukkan data-data yang berkaitan dengan penjadwalan ini ke sistem.

9. Menguji Hasil

Pengujian hasil pengolahan data di implementasikan menggunakan bahasa pemrograman PHP. Pengujian dilakukan untuk membandingkan hasil yang didapatkan pada tahap implementasi sistem yang dibuat.

\section{Evaluasi Sistem}

Setelah sistem diterapkan maka tahap terakhir dari pengembangan system ini adalah mengevaluasi kebutuhan dari sistem yang sedang berjalan. Agar system yang dibuat dapat berguna dan sesuai dengan kebutuhan pengguna sistem.

\section{HASIL DAN PEMBAHASAN}

\section{Analisa Sistem Penjadwalan Menggunakan GA}

Dalam perancangan sistem penjadwalan menggunakan algoritma genetika, tahap awal yang dilakukan adalah menentukan populasi awal, menentukan batasan penjadwalan, merepresentasikan nilai kromosom, menginisialisasi populasi awal, melakukan seleksi, crossover, mutasi, hingga mencapai kondisi selesai. Gambar 2 menerangkan alir algoritma genetika secara umum.

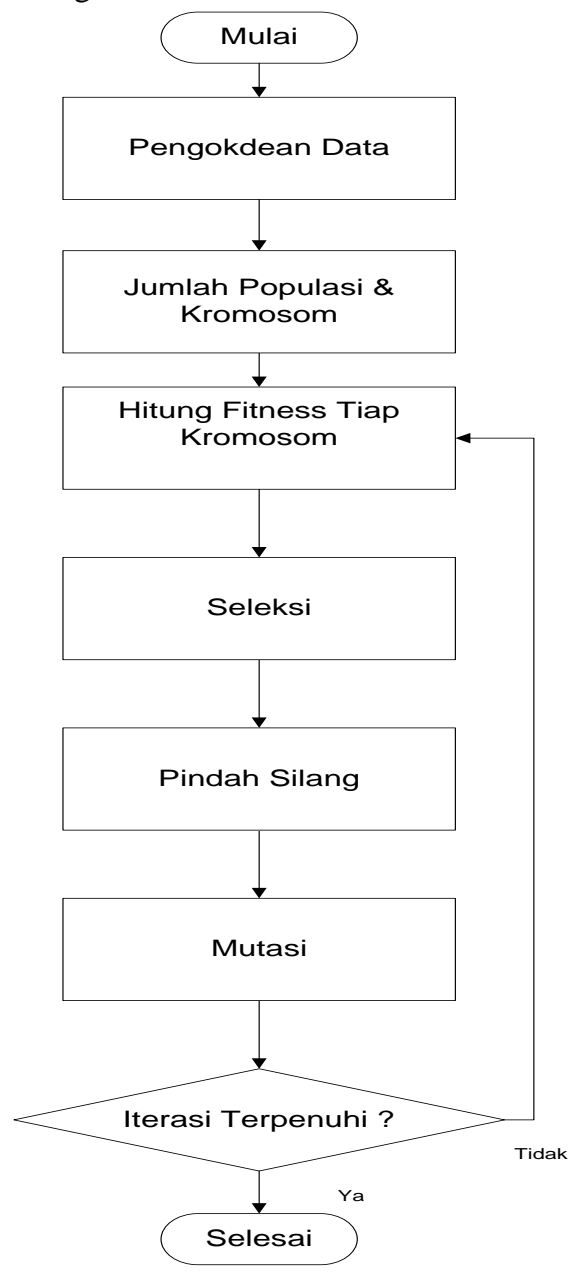

Gambar 2 : Flowchart Penjadwalan Algoritma Genetika

1. Populasi Awal

Dalam menetukan sebuah populasi, sebelumnya dirancang dulu bentuk kromosom yang akan dipakai dalam peracangan sistem penjadwalan, bentuk kromosom yang dipakai adalah sebagai berikut :

1. Kode mata pelajaran (M)

2. Kode guru $(\mathrm{G})$

3. Kode kelas $(\mathrm{K})$

4. Kode jam pelajaran (T)

sehingga susunan object pada kromosom yang baru tersebut adalah : $<\mathrm{M}, \mathrm{G}, \mathrm{K}, \mathrm{T}\rangle$. gambar 4.3 menerangkan diagram Alir pembentukan kromosom. 


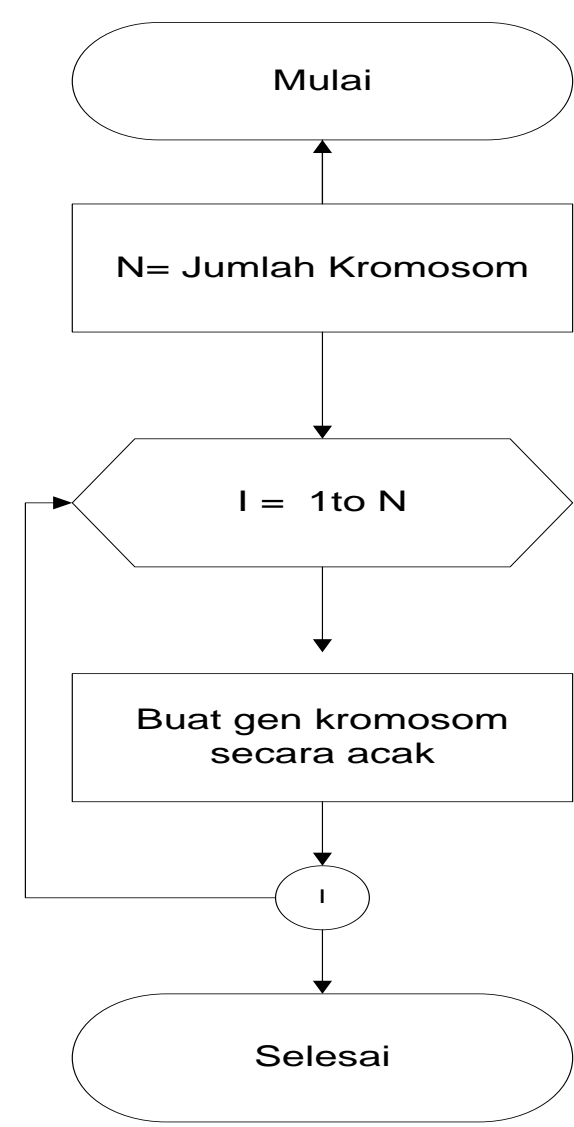

Gambar 3 Flowchart Pembentukan Kromosom

Panjang suatu kromosom adalah gabungan gen berdasarkan jumlah seluruh mata pelajaran dan kelas yang ditawarkan pada semester aktif. Satu gen berisi informasi waktu dan jam untuk satu mata pelajaran dan kelas. Sebagai contoh untuk inisialisasi pembentukan kromosom, misalkan ada sebaran mata pelajaran pada Tabel 1, sebaran jam pelajaran pada Tabel 2.

Tabel 1 : Contoh Sebaran Mata Pelajaran

\begin{tabular}{|c|c|c|c|c|c|c|}
\hline No & $\begin{array}{c}\text { Id mata } \\
\text { pelajara } \\
n\end{array}$ & $\begin{array}{l}\text { Nama } \\
\text { Mapel }\end{array}$ & $\begin{array}{c}\text { Id } \\
\text { guru }\end{array}$ & $\begin{array}{c}\text { Nam } \\
\text { a } \\
\text { Guru }\end{array}$ & $\begin{array}{c}\text { Id } \\
\text { kelas }\end{array}$ & $\begin{array}{l}\text { Nama } \\
\text { Kelas }\end{array}$ \\
\hline 1 & M01 & $\begin{array}{c}\text { Mengelola } \\
\text { Induk } \\
\text { Ikan }\end{array}$ & G01 & $\begin{array}{c}\text { Tati } \\
\text { Erwi } \\
\text { na, } \\
\text { S.Pi }\end{array}$ & K01 & $\begin{array}{c}\text { X } \\
\text { Agribisnis } \\
\text { Perikaan }\end{array}$ \\
\hline 2 & M02 & $\begin{array}{c}\text { Uji Coba } \\
\text { Pakan } \\
\text { Alami }\end{array}$ & G01 & $\begin{array}{c}\text { Tati } \\
\text { Erwi } \\
\text { na, } \\
\text { S.Pi }\end{array}$ & K01 & $\begin{array}{c}\text { X } \\
\text { Agribisnis } \\
\text { Perikaan }\end{array}$ \\
\hline 3 & M03 & $\begin{array}{c}\text { Memijah } \\
\text { Ikan }\end{array}$ & G02 & $\begin{array}{c}\text { Errni } \\
\text { juita, } \\
\text { S.Pi }\end{array}$ & K01 & $\begin{array}{c}\mathrm{X} \\
\text { Agribisnis } \\
\text { Perikaan }\end{array}$ \\
\hline 4 & M04 & $\begin{array}{c}\text { Matematik } \\
\text { a }\end{array}$ & G03 & $\begin{array}{c}\text { Fajria } \\
\text { Putri } \\
\text { M.S. } \\
\text { Pd }\end{array}$ & K01 & $\begin{array}{c}\mathrm{X} \\
\text { Agribisnis } \\
\text { Perikaan }\end{array}$ \\
\hline
\end{tabular}

Tabel 2: Contoh Sebaran Waktu

\begin{tabular}{|l|l|l|}
\hline Index waktu & Hari & Waktu \\
\hline T01 & Senin & $07.30-08.05$ \\
\hline T02 & Selasa & $07.30-08.05$ \\
\hline T03 & Rabu & $08.10-08.50$ \\
\hline T04 & Kamis & $11.05-11.45$ \\
\hline T05 & Jumat & $12.25-12.45$ \\
\hline T06 & Sabtu & $13.20-13.55$ \\
\hline
\end{tabular}

Terdapat jadwal kosong pada hari senin pagi jam 07.30 - 08.10 untuk upacara pagi. Diasumsikan dalam satu populasi yang terbentuk berjumlah 4 kromosom sesuai dengan jumlah mata pelajaran yang ada serta masing-masing kromosom memilik 4 gen. Untuk penyusunan populasi awal diambil dari tabel sebaran mata pelajaran dan tabel sebaran waktu, dari tabel tersebut dipilih secara acak untuk penyusunan populasi, dimana M01 adalah kode untuk mata pelajaran 1, G01 untuk kode guru 1, K01 untuk kode kelas 1, dan T01 untuk kode waktu 1. Berikut adalah susunan pupulasi awal yang telah disusun secara acak.

\section{K01G01M01T01 K01G02M04T04 K01G02M03T02 K01G02M02T03}

K01G03M01T04 K01G03M04T02 K01G02M02T01 K01G03M03T03

K01G01M02T03 K01G02M02T01 K01G02M03T04 $\underline{\text { K01G01M04T01 }}$

\section{K01G01M01T02 K01G02M03T03}

K01G02M04T04 K01G01M01T02

Urutan kode tiap gen mewakili kode mata pelajaran, kode guru, kode kelas dan kode waktu. Penempatan urutan kode tiap gen dilakukan secara acak. Pada contoh merupakan jumlah dari seluruh mata pelajaran dan jam yang ditawarkan.

\section{Fungsi Fitness}

Dalam tahap seleksi dilakukan pemilihan untuk menentukan individu induk terbaik dengan fungsi fitness. Hasil dari fungsi ini menandakan seberapa optimal solusi yang didapat karena hanya kromosom yang memiliki nilai fitness tertinggi yang akan bertahan. Dalam kasus ini setiap pelanggaran yang ada diberikan nilai 1 dan agar tidak terjadi nilai fitness tak terhingga maka total dari pelanggaran kita tambahkan nilai 1. Beberapa batasan yang diutamakan dalam penyusunan jadwal ini adalah :

a. Guru tidak boleh dijadwalkan mengajar lebih dari satu kali pada satu waktu yang bersamaan. 
b. Satu kelas tidak boleh dijadwalkan lebih dari satu kali pada waktu yang bersamaan.

\section{K01G01M01T01 K01G02M04T04 K01G02M03T02 K01G02M02T03 \\ K01G01M01T04 K01G01M04T02 K01G02M02T01 K01G03M03T03 \\ K01G02M02T03 K01G02M02T01 K01G02M03T04 K01G01M04T01 \\ K01G01M01T02 K01G02M03T03 \\ K01G02M04T04 K01G01M01T02}

Dari susunanppopulasi di atas dapat dilihat pada kromosom 1 \& 2 tidak terdapat pelanggaran batatasan, dan pada kromosom ke 3 \& 4 terdapat pelanggaran batasan dimana pada kromosom 3 terdapat dua gen yaitu gen 2 dan 4 yang memiliki kesamaan pada kelas (K01) dan waktu (T01), pada kromosom ke 4 juga terdapat pelanggaran yaitu pada gen 1 dan 4 yang memiliki kesamaan kelas (K01), guru (G01), mata pelajaran (M01) dan waktu (T02). Dari pelanggaran yang ada akan menghasilkan nilai fitness sebagai berikut :

Fitness kromosom $1=\frac{1}{1+(0+0+0+0)}=1$

Fitness kromosom $2=\frac{1}{1+(0+0+0+0)}=1$

Fitness kromosom $3=\frac{1}{1+(1+0+0+1)}$

$$
=0,33
$$

Fitness kromosom $4=\frac{1}{1+(1+1+1+1)}=0,2$

\section{Seleksi}

Pada tahap seleksi untuk pembentukan populasi baru, metode yang digunakan adalah metode seleksi roulette-wheele, masing-masing kromosom menempati potongan-potongan lingkaran secara proporsional sesuai dengan nilai fitness nya. Langkah pertama metode ini adalah dengan menghitung total nilai fitness seluruh kromosom seperti pada tabel 3 berikut :

Tabel 3: Tabel Nilai Fitness

\begin{tabular}{|c|c|}
\hline Kromosom & Nilai fitness \\
\hline 1 & 1 \\
\hline 2 & 1 \\
\hline 3 & 0,33 \\
\hline 4 & 0,2 \\
\hline Total nilai fitness & 2,53 \\
\hline
\end{tabular}

Langkah kedua adalah menghitung probabilitas setiap kromosom dengan membagi nilai fitness tiap kromosom dengan total nilai fitness sehingga didapat hasil seperti pada tabel 4 berikut :

Tabel 4. Tabel Probabilitas Nilai Fitness

\begin{tabular}{|c|c|}
\hline Kromosom & Probabilitas \\
\hline 1 & $1 / 2,53=0,39$ \\
\hline 2 & $1 / 2,53=0,39$ \\
\hline 3 & $0,33 / 2,53=0,14$ \\
\hline 4 & $0,2 / 2,53=0,08$ \\
\hline
\end{tabular}

ketiga adalah menempatkan masing-masing kromosom pada interval nilai [0-1]. Dapat dilihat pada tabel 5.

Tabel 5 : Tabel Interval Nilai Probabilitas

\begin{tabular}{|c|l|}
\hline Kromosom & \multicolumn{1}{|c|}{ Interval nilai } \\
\hline 1 & $0-0,39$ \\
\hline 2 & $0,40-0,78$ \\
\hline 3 & $0,79-0,92$ \\
\hline 4 & $0,93-1$ \\
\hline
\end{tabular}

Untuk menentukan susunan populasi baru hasil seleksi maka dibangkitkan bilangan acak (bilangan random) antara [ $0-1$ ], dimisalkan bilangan yang dibangkitkan adalah [ 0,$2 ; 0,8 ; 0,5 ; 0,95$ ]. Dari nilai yang dibangkitkan secara acak dapat dilihat kromosom yang memilki nilai 0.2 adalah kromosom 1 yaitu dengan interval nilai $0 \quad-0.39$, jadi kromosom 1 tidak mengalami seleksi, selnjutnya kromosom yang memiliki nilai 0.8 adalah kromosom ke 3 dengan interval 0,79 - 0.92 maka kromosom ke 3 mengalami seleksi ke kromosom ke 2, dan secara otomatis kromosom ke 2 juga mengalami seleksi dengan mengisi posisi di kromosom 3, dan kromosom yang memiliki nilai 0.95 adalah kromosom keempat dengan interval nilai 0,93 - 1, dengan demikian kromosom ke 4 juga tidak mengalami seleksi karena nilai acak yang dubangkitkan sesuai dengan interval nilai pada kromosom. Maka susunan kromosom populasi baru hasil proses seleksi adalah :

K01G01M01T01 K01G02M04T04 K01G02M03T02 K01G02M02T03

K01G02M02T03 K01G02M02T01 K01G02M03T04 $\underline{\mathrm{K} 01 \mathrm{G} 01 \mathrm{M} 04 \underline{\mathrm{T} 01}}$

K01G01M01T04 K01G01M04T02 K01G02M02T01 K01G03M03T03

K01G01M01T02 K01G02M03T03 K01G02M04T04 K01G01M01T02 


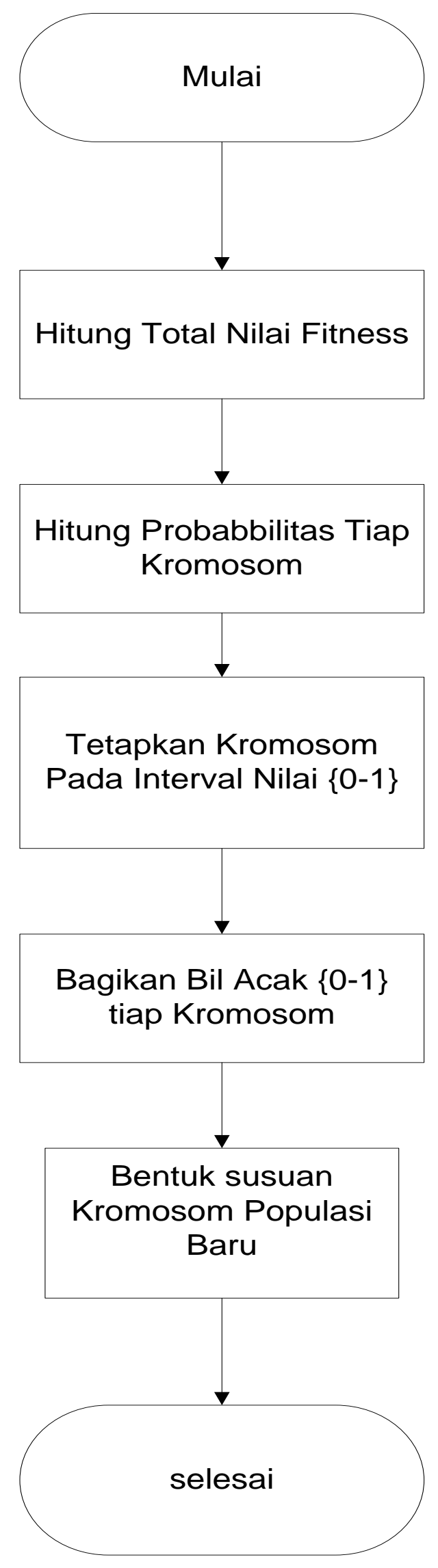

Gambar 3: Flowchart Seleksi
4. Kawin Silang

Kawin silang (CrossOver) digunakan sebagai metode pemotongan kromosom secara acak (random) dan merupakan penggabungan bagian pertama dari kromosom induk 1 dengan bagian kedua dari kromoson induk 2. Kawin silang (crossover) dilakukan dengan mengawinkan gen yang berjenis sama dengan merandom baris - baris tersebut. Kawin silang dilakukan jika ada nilai bilangan random yang dibangkitkan suatu kromosom kurang dari nilai probabilitas yang sudah diset, dimana nilai bilangan random dimisalkan adalah $[0,2 ; 0,8 ; 0,5 ; 0,95]$, dan nilai probabilitas pada umumnya diset minimal 0,5 (mendekati nilai 1). Metode kawin silang yang umum digunakan adalah pindah silang satu titik potong. Satu titik potong dipilih secara acak kemudian bagian pertama dari kromosom induk 1 digabungkan dengan bagian kedua dari kromosom induk 2 .

Bilangan acak yang dibangkitkan untuk menentukan posisi titik potong adalah $\quad[1-\mathrm{N}$ ] dimana $\mathrm{N}$ merupakan banyaknya jumlah gen dalam satu kromosom. Dari contoh nilai bilangan random yang dibangkitkan diatas yang mengalami crossover adalah kromosom 1 dan 3 karena memiliki nilai kurang dari nilai probabilitas yang telah ditetapkan, dimana kromosom 1 dan 3 bernilai 0,2 dan 0,5. Dan untuk posisi potong dipilih adalah posisi gen ke -2 , maka proses kawin silangnya adalah :

Kromosom 1 = K01G01M01T01 K01G02M04T04 K01G02M03T02 K01G02M02T03

Kromosom 3 = K01G01M01T04 K01G01M04T02 K01G02M02T01 K01G03M03T03

Hasil kawin silang kedua kromosom tersebut seperti berikut :

Kromosom 1 = K01G01M01T01 K01G01M04T02 K01G02M02T01 K01G03M03T03

Kromosom $3=\underline{\text { K01G01M01T04 }} \underline{\text { K01G02M04T04 }}$ K01G02M03T02 K01G02M02T03

Fitness kromosom 1 sesudah pindah silang

$$
=\frac{1}{1+(1+0+0+1)}=0.33
$$

Fitness kromosom 3 sesudah pindah silang

$$
=\frac{1}{1+(1+0+0+1)}=0.33
$$




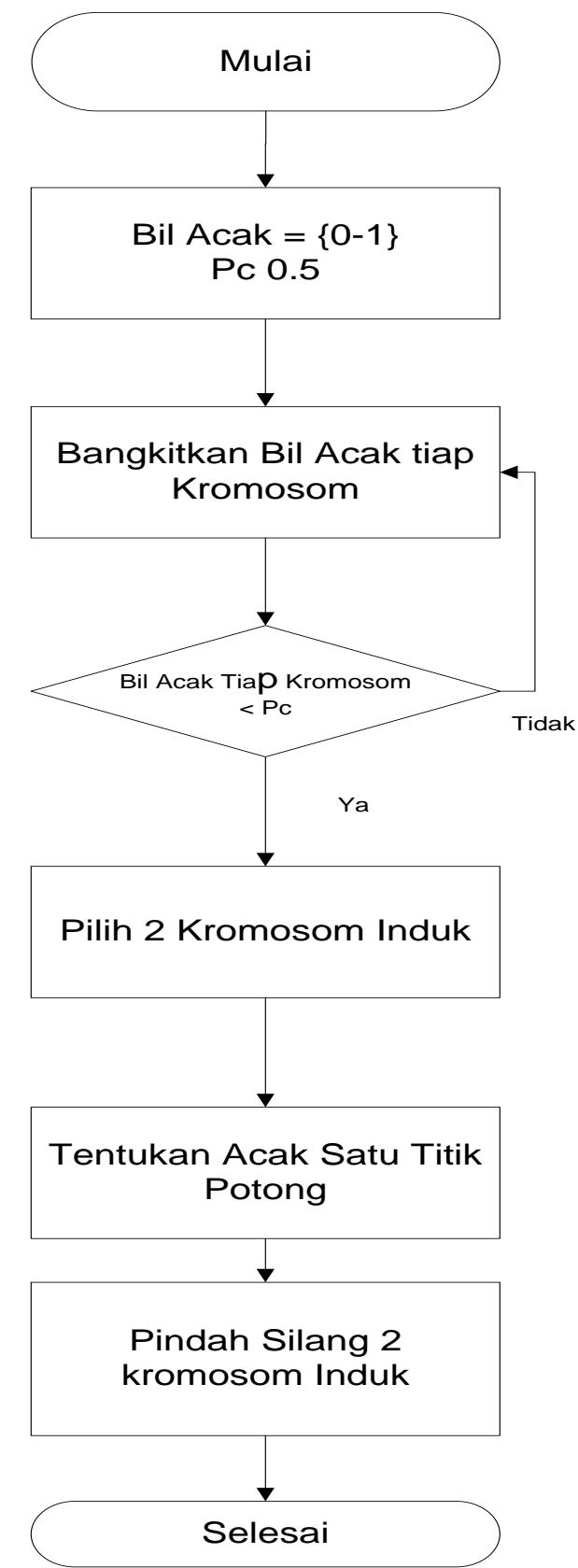

Gambar 4. Flowchart Kawin Silang

\section{Mutasi}

Setelah dilakukannya proses kawin silang maka selanjutnya dilakukan proses mutasi. Proses mutasi adalah suatu proses kemungkinan memodifikasi informasi gen-gen pada suatu kromosom Perubahan ini dapat membuat solusi duplikasi menjadi memiliki nilai fitness yang lebih rendah maupun lebih tinggi daripada solusi induknya. Jika ternyata diperoleh solusi yang memiliki fitness yang lebih tinggi maka hal itulah yang diharapkan. Tetapi jika diperoleh solusi dengan nilai fitness yang lebih rendah maka bisa jadi pada iterasi berikutnya diperoleh solusi hasil mutasi yang lebih baik nilai fitnessnya dari pada solusi induknya.

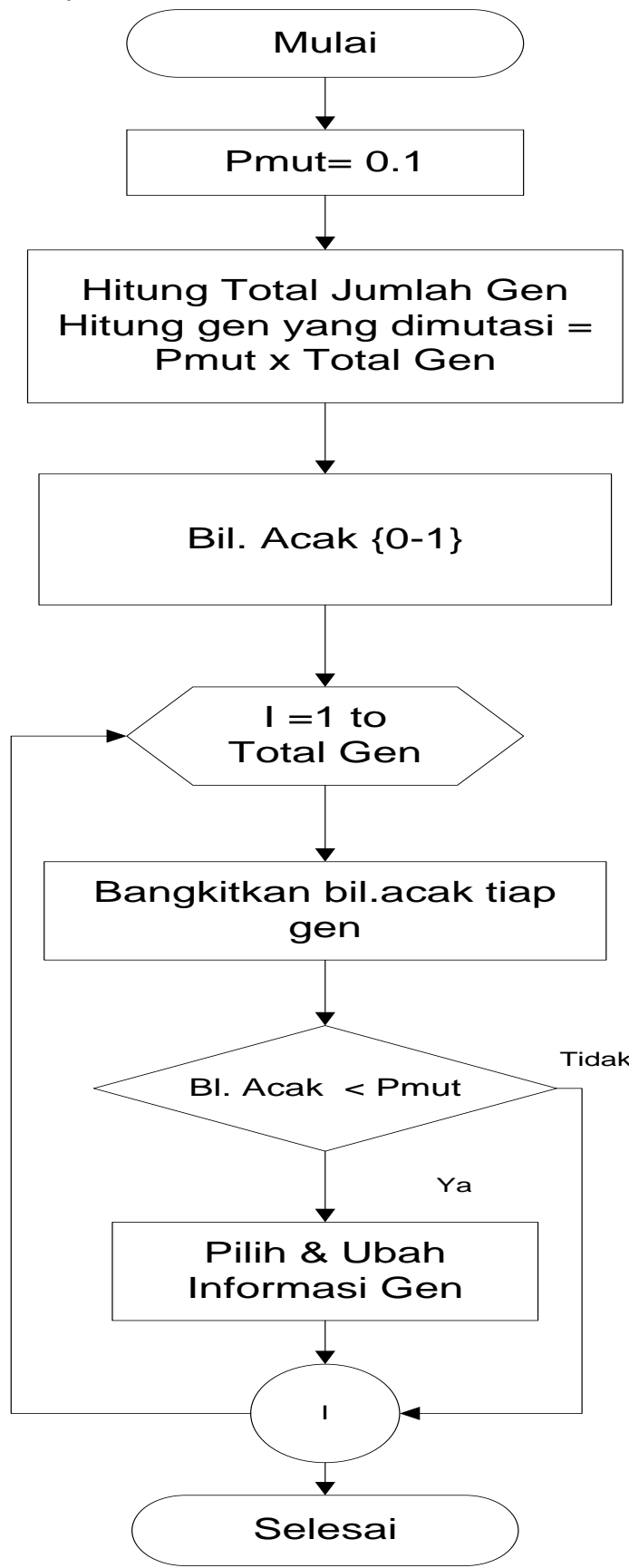

Gambar 5: Flowchart Mutasi

Untuk semua gen yang ada, jika bilangan acak (random) yang dibangkitkan kurang dari probabilitas mutasi (Pmut) yang telah ditentukan maka beberapa informasi gen akan dirubah dengan menggunakan metode pengkodean nilai untuk menghasilkan nilai fitness yang makin baik dan memperbaiki peletakan mata pelajaran yang kurang sesuai dengan yang diharapkan. Untuk mendapatkan posisi gen yang akan dimutasi maka perlu dihitung jumlah total gen dalam satu populasi yaitu : 
Total gen $=$ Jumlah gen dalam satu kromosom $\mathrm{x}$ Jumlah kromosom yang ada.

Berdasarkan contoh yang ada maka total gen adalah 4 × $4=16$. Probabilitas mutasi ditetapkan 0,1 maka diharapkan mutasi yang terjadi adalah : 0,1 x 16 $=1,6=2$. Maka ada 2 gen yang akan mengalami mutasi. Selanjutnya dilakukan iterasi sebanyak jumlah total gen [0-16] dan membangkitkan bilangan acak untuk tiap iterasi antara [0-1]. Diasumsikan gen yang mendapatkan bilangan di bawah probabilitas mutasi adalah gen 2 dan 3 pada kromosom 1. Informasi dalam gen yang akan diubah adalah waktu pelajaran, maka hasil mutasi pada kromosom tersebut adalah :

Kromosom sebelum mutasi $=\underline{\text { K01G01M01T01 }}$ K01G01M04T02 K01G02M02T01 K01G03M03T03 Kromosom setelah mutasi = K01G01M01T01 K01G02M04T02 K01G02M02T04 K01G03M03T03

Dari proses mutasi di atas sehingga akan menghasilkan susunan kromosom baru sebagai berikut :

\section{K01G01M01T01 K01G02M04T02 K01G02M02T04 K01G03M03T03 \\ K01G02M02T03 K01G02M02T01 K01G02M03T04 K01G01M04T01 \\ K01G01M01T04 K01G02M04T04 K01G02M03T02 K01G02M02T03 \\ K01G01M01T02 K01G02M03T03 \\ K01G02M04T04 K01G01M01T02}

Nilai fitness masing-masing kromosom dari hasil proses mutasi di atas adalah :

Fitness kromosom 1 sesudah Mutasi

$$
=\frac{1}{1+(0+0+0+0)}=1
$$

Fitness kromosom 2 sesudahMutasi

$$
=\frac{1}{1+(1+0+0+1)}=0.33
$$

Fitness kromosom 3 sesudah Mutasi

$$
=\frac{1}{1+(1+0+0+1)}=0.33
$$

Fitness kromosom 4 sesudah mutasi

$$
=\frac{1}{1+(1+1+1+1)}=0.2
$$

Dari hasil nilai fitness di atas dipilih kromosom 1 sebagai kromosom yang memiliki nilai fitness terbaik karena tidak terdapat pelanggaran yang ditetapkan dan merupakan solusi yang diinginkan. . Hasil dari seluruh proses algoritma sudah sesuai dengan data asli yang diharapan, bahwa guru yang sama tidak dijadwalkan mengajar lebih dari satu kali pada satu waktu yang bersamaan. Satu kelas tidak dijadwalkan lebih dari satu kali pada waktu yang bersamaan. Hasil akhir dari proses dapat dilihat pada tabel 4.8.

\begin{tabular}{|c|c|c|c|c|c|c|c|}
\hline $\begin{array}{l}\text { Id } \\
\text { Ma } \\
\text { pel }\end{array}$ & $\begin{array}{l}\text { Nama } \\
\text { Mapel }\end{array}$ & $\begin{array}{c}\text { Id } \\
\text { Gur } \\
\mathrm{u}\end{array}$ & $\begin{array}{l}\text { Nama } \\
\text { Guru }\end{array}$ & $\begin{array}{l}\text { Id } \\
\text { kel } \\
\text { as }\end{array}$ & Kelas & $\begin{array}{l}\text { Id } \\
\text { W } \\
\text { ak } \\
\text { tu }\end{array}$ & $\begin{array}{c}\text { Wakt } \\
\mathrm{u}\end{array}$ \\
\hline $\begin{array}{c}\text { M0 } \\
1\end{array}$ & $\begin{array}{c}\text { Meng } \\
\text { elola } \\
\text { Induk } \\
\text { Ikan }\end{array}$ & G01 & $\begin{array}{c}\text { Tati } \\
\text { Erwina, } \\
\text { S.Pi }\end{array}$ & $\begin{array}{c}\mathrm{K} 0 \\
1\end{array}$ & $\begin{array}{c}X \\
\text { Agrib } \\
\text { isnis } \\
\text { Perik } \\
\text { aan }\end{array}$ & $\begin{array}{c}\mathrm{T} \\
01\end{array}$ & $\begin{array}{c}07.30 \\
- \\
08.05\end{array}$ \\
\hline $\begin{array}{c}\text { M0 } \\
4\end{array}$ & $\begin{array}{l}\text { Mate } \\
\text { matik } \\
\text { a }\end{array}$ & G02 & $\begin{array}{c}\text { Fajria } \\
\text { Putri M, } \\
\text { S.Pd }\end{array}$ & $\begin{array}{c}\mathrm{K} 0 \\
1\end{array}$ & $\begin{array}{c}\mathrm{X} \\
\text { Agrib } \\
\text { isnis } \\
\text { Perik } \\
\text { aan }\end{array}$ & $\begin{array}{c}\mathrm{T} \\
02\end{array}$ & $\begin{array}{c}07.30 \\
- \\
08.05\end{array}$ \\
\hline $\begin{array}{c}\text { M0 } \\
2\end{array}$ & $\begin{array}{c}\text { Uji } \\
\text { Coba } \\
\text { Pakan } \\
\text { Alami }\end{array}$ & G02 & $\begin{array}{c}\text { Errni } \\
\text { juita, } \\
\text { S.Pi }\end{array}$ & $\begin{array}{c}\text { K0 } \\
1\end{array}$ & $\begin{array}{c}\mathrm{X} \\
\text { Agrib } \\
\text { isnis } \\
\text { Perik } \\
\text { aan }\end{array}$ & $\begin{array}{c}\mathrm{T} \\
04\end{array}$ & $\begin{array}{c}08.40 \\
- \\
09.15\end{array}$ \\
\hline $\begin{array}{c}\text { M0 } \\
3\end{array}$ & $\begin{array}{c}\text { Memi } \\
\text { jah } \\
\text { Ikan }\end{array}$ & G02 & $\begin{array}{c}\text { Errni } \\
\text { juita, } \\
\text { S.Pi }\end{array}$ & $\begin{array}{c}\mathrm{K} 0 \\
1\end{array}$ & $\begin{array}{c}\mathrm{X} \\
\text { Agrib } \\
\text { isnis } \\
\text { Perik } \\
\text { aan }\end{array}$ & $\begin{array}{c}\mathrm{T} \\
03\end{array}$ & $\begin{array}{c}08.05 \\
- \\
08.40\end{array}$ \\
\hline
\end{tabular}

Kromosom 1 = K01G01M01T01 K01G02M04T02 K01G02M02T04 K01G02M03T03

Tabel 6. Contoh Tabel Hasil Proses

6. Kondisi Selesai

Kondisi selesai yang dapat menghentikan proses algoritma genetika ini adalah jika jumlah generasi atau iterasi maksimum telah

\section{SIMPULAN}

Berdasarkan pada hal-hal yang penulis telah bahas pada bab-bab sebelumnya, penulis menarik kesimpulan sebagai berikut :

1. Proses pembuatan jadwal mata pelajaran sekolah dasr dapat dilakukan dengan menggunakan Algoritma Genetika. Melalui langkah-langkah yang digunakan dalam Algoritma Genetika yaitu menentukan batasan penjadwalan, merepresentasikan nilai kromosom, menginisialisasi populasi awal, melakukan seleksi, crossover, mutasi, hingga mencapai kondisi selesai.

2. Output dari sistem penjadwalan ini berupa jadwal mata pelajaran sekolah dasar yang tidak bentrok dan dapat membantu pihak sekolah dalam penetuan jadwal mengajar pada SMKN 3 Pariaman. 


\section{DAFTAR PUSTAKA}

[1] Adi Slamet Kusumawardana dan Irhamah (2013). "Vehicle Routing Problem With Stochastic Demands dengan Metode Hibrid Simulated Annealing-Algoritma Genetika." Statistika, Vol. 1, No. 2.

[2] Akhmad Yusuf dan Oni Soesanto (2012). "Algoritma Genetika pada Penyelesaian Akar Persamaan Sebuah Fungsi." Jurnal Matematika Murni dan Terapan, Vol.6 No.2.

[3] Tamilarasi and T. Anantha kumar (2010). "An enhanced genetic algorithm with simulated annealing for job-shop scheduling." International Journal of Engineering, Science and Technology, Vol. 2, No. 1, 2010.

[4] Bhakti Yudho Suprapto dan Sariman (2012). "Metode Algoritma Genetika dengan Sistem Fuzzy Logic untuk Penentuan Parameter Pengendali PID." Jurnal Rekayasa Elektrika, Vol. 10, No. 1.

[5] Gaurav Govind Keswani (2013). "Artificial Intelligence- Is Our Future Bright or Bleak." International Journal of Engineering and Advanced Technology (IJEAT) ISSN: 2249 8958, Volume-2, Issue-4

[6] Joko Lianto Buliali, Darlis Herumurti dan Giri Wiriapradja (2008)., "Penjadwalan Matakuliah dengan Menggunakan Algoritma Genetika dan Metode Constraint Satisfaction." JUTI, Volume 7, Nomor 1.
[7] Kon Chon Min, Abdullah Mat Rashid and Mohd Ibrahim Nazri (2012). “ Teachers' Understanding and Practice towards Thematic Approach in Teaching Integrated Living Skills (ILS) in Malaysia." International Journal of Humanities and Social Science, Vol. 2 No. 23.

[8] Made Darma Yunantara, I Gede Santi Astawa, dan Ngr. Agus Sanjaya ER (2012). "Analisis dan Implementasi Penjadwalan dengan Menggunakan Pengembangan Model Crossover Dalam Algoritma Genetika." Jurnal Elektronik Ilmu Komputer, Universitas Udayana, Vol.1, No.2.

[9] Putra Bahtera Jaya Bangun, Sisca Octarina, dan Gusti Ahta Virgo (2012). "Penerapan Konsep Algoritma Genetika untuk Penjadwalan Kegiatan Perkuliahan Semester Ganjil Kurikulum 2012 di Jurusan Matematika FMIPA UNSRI." Jurnal Penelitian Sains, Volume 15 Nomor 2(A).

[10] Wiga Ayu Puspaningrum, Arif Djunaidy, dan Retno Aulia Vinarti (2013). "Penjadwalan Mata Kuliah Menggunakan Algoritma Genetika di Jurusan Sistem Informasi. " Jurnal Teknik Pomits, Vol. 2, No. 1.

[11] William Tanujaya, Dian Retno Sari Dewi dan Dini Endah (2011). "Penerapan Algoritma Genetik untuk Penyelesaian Masalah Vehicle Routing di PT.MIF." WIDYA TEKNIK, Vol. 10, No.1.

[12] Yoyon Arie Budi (2012). "Optimalisasi Radio Base Station dengan Metode Algoritma Genetika." JIKOM, Volume 2, Nomor 2. 